\title{
Consanguinity in the Contemporary World
}

\author{
Giovanni Romeo ${ }^{a, b} \quad$ Alan H. Bittles ${ }^{c, d}$ \\ ${ }^{a}$ Alma Mater Studiorum, and ${ }^{b}$ European School of Genetic Medicine, Bologna, Italy; ${ }^{c}$ Murdoch University, and \\ ${ }^{\mathrm{d}}$ Edith Cowan University, Perth, W.A., Australia
}

In medical genetics literature, a consanguineous marriage is usually defined as the union of a couple related as second cousins or closer $(F=0.0156)$ [1], although in some subpopulation isolates, for example in Finland, it has been demonstrated that more distant genetic relationships may also be important in the expression of rare recessive disorders [2]. Until the middle of the 19th century, close-kin marriage was commonplace and widely accepted in Western countries, albeit with general disapproval from the Orthodox Church and diocesan dispensation required for cousin marriages conducted within the Roman Catholic Church [3].

A significant change in the public attitude occurred thereafter, with a gradual decline in the popularity of consanguineous unions in Western Europe, where affine relationships had previously been regarded with suspicion, in particular between a man and his deceased wife's sister in Victorian England [4]. At the same time, in the USA, an increasing number of states introduced a legislation banning first-cousin marriages [5]. These trends have continued so that, with the exception of recent migrant communities, close-kin unions now account for $<1 \%$ of marriages in Western countries (www.consang.net; fig. 1).

\section{KARGER}

E-Mail karger@karger.com

www.karger.com/hhe
The rarity of consanguineous marriage in much of the industrialized world, and the current restriction or outright prohibition of first-cousin unions in a majority of US states and in East Asian countries such as China, North and South Korea and the Philippines, has led many commentators to overlook the fact that the Out-of-Africa migration some 60,000-70,000 years ago had been undertaken by quite small numbers of individuals. Current estimates of the numbers of migrants generally agree on a maximum of approximately 10,000 breeding individuals [6-9], but with some simulations suggesting as few as 700 or even 450 emigrating adults $[10,11]$. There is some controversy as to whether the migration from Africa was accompanied by one or more bottlenecks [12-14] and the possibility of limited back-migration to North Africa [15], but population expansions over ensuing generations have led to the fact that some 6.0 billion of the current global population of 7.3 billion are Out-of-Africa descendants[16].

It seems inevitable that reproduction would have involved closely related individuals during the early days of these population expansions, when human groups remained small in number, largely nomadic, and geographically scattered, and this pattern of partner choice per-
(C) 2014 S. Karger AG, Basel

0001-5652/14/0774-0006\$39.50/0
Prof. Alan H. Bittles

Centre for Comparative Genomics, Murdoch University South Street, Murdoch

Perth, WA 6150 (Australia)

E-Mail abittles@ccg.murdoch.edu.au or a.bittles@ecu.edu.au 


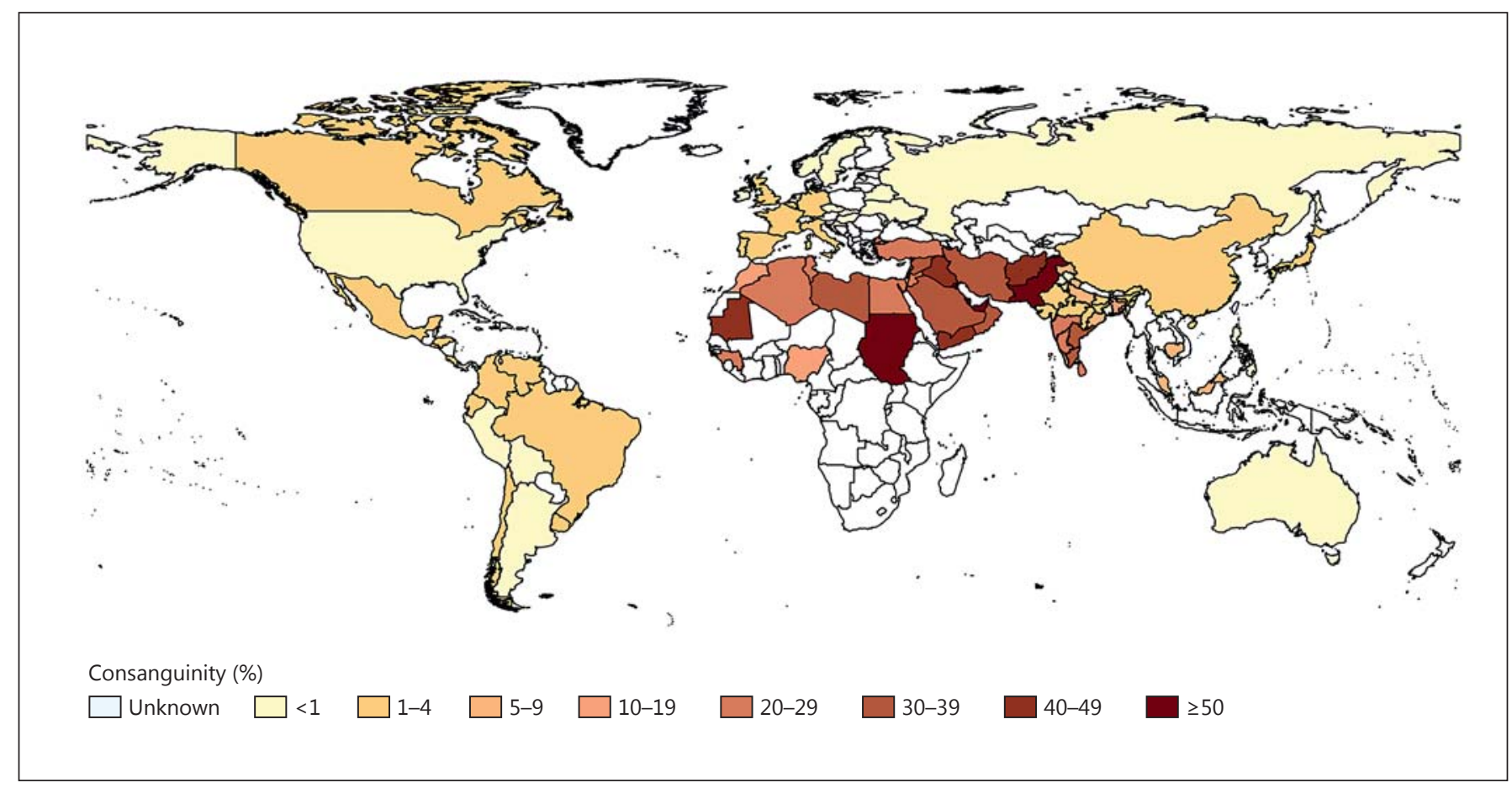

Fig. 1. Global map of consanguineous marriages.

sisted well into historical times. It therefore is no surprise that genomic studies on samples from the HGDP-CEPH [17] and HapMap panels [18-20] have demonstrated the existence of previously unsuspected genetic relationships. Even in a recent heterogeneous sample of 5,000 Europeans drawn from both isolated and cosmopolitan communities, tens of thousands of second- to ninthcousin pairs have been identified [21].

From a present-day consanguinity perspective, most attention is paid to populations and societies where closekin marriage continues to be strongly favored. As illustrated in figure 1, the regions which are mainly involved are North and Sub-Saharan Africa, the Middle East, and West, Central and South Asia, with a conservatively estimated 1.1 billion people resident in countries where 20$50 \%$ of marriages or more are consanguineous $[3,22]$. This emphasis is reflected in the present special issue of Human Heredity, with a strong focus on the populations of these regions and on migrant populations with origins in different parts of Asia and Africa.

Within genetics, contemporary medical and scientific attention on consanguineous marriage continues to be largely focused on rare autosomal recessive diseases. But from an overall population and health perspective, consanguinity is a much more extensive and complex topic

Consanguinity in the Contemporary

World that also involves major social, economic, and demographic influences [23]. Genome analysis is, however, the principal unifying theme, since next-generation sequencing is increasingly indispensable in population profiling [24] and disease diagnosis [25] and is thus central to investigations into the biological and health outcomes of consanguinity. In this context, consanguinity serves as an effective magnifying device for the identification of genes involved in rare autosomal recessive disorders, based on autozygosity mapping and exome homozygosity (EXHOM) approaches [26, 27].

In endogamous populations, the application of whole genome analysis for genes implicated in the expression of complex genetic disorders will be of major importance to medicine in the coming years. This investigative approach has been elegantly demonstrated in the ongoing Sardinia project [28], which employs a combined strategy of lowcoverage whole genome sequencing and SNP arrays to demonstrate highly significant associations between rare or low-frequency genetic variants and specific cellular phenotypes. The genetic contribution of regulatory variants to quantitative traits can in turn be identified, thus helping to elucidate their involvement in disease.

Studies on highly endogamous populations can also be very useful in estimating human mutation rates, as has 
recently been reported with the Hutterite community, Anabaptist farmers who have lived in close-knit colonies in the plains of the USA and Canada since the late 19th century. As the descendants of a small group of genetically and demographically well-defined European founders, Hutterite individuals carry large segments of their genome that are autozygous. The accumulation of mutations in alleles in autozygous segments during recent generations thus makes it possible to identify the occurrence of new mutational events [29].

The analysis of disease-causing mutations in the children of consanguineous parents has additionally facilitated the calculation of reliable incidence estimates for autosomal recessive disorders [30-33] by essentially following the same strategy which in the pre-molecular era was based solely on demographic data [34-37]. During that earlier era, consanguineous marriages showed major variations in space and time for different populations. National data could therefore only be collected in a systematic way for Italy, thanks to the unique resources of the Vatican Archives for consanguineous marriage dispensations available for the whole Italian population for the period of 1600-1964 [38]. Given the rapidly increasing access to next-generation sequencing facilities, together with a very significant lowering of costs, a major expansion of molecular epidemiological studies on disease genes based on consanguineous families and communities can be predicted within the near future.

\section{References}

1 Bittles AH: Consanguinity and its relevance to clinical genetics. Clin Genet 2001;60:8998.

2 Bittles AH: Consanguinity, genetic drift and genetic diseases in populations with reduced numbers of founders; in Speicher M, Antonarakis SE, Motulsky AG (eds): Human Genetics - Principles and Approaches, ed 4. Heidelberg, Springer, 2009, pp 507-528.

3 Bittles AH: Consanguinity in Context. Cambridge, Cambridge University Press, 2012.

4 Anderson NF: The 'marriage with a deceased wife's sister bill' controversy: incest anxiety and the defense of family purity in Victorian England. J Br Stud 1982;21:67-86.

5 Ottenheimer M: Forbidden Relatives: The American Myth of Cousin Marriage. Chicago University of Illinois Press, 1996.

6 Harpending HC, Batzer MA, Gurven M, Jorde LB, Rogers AR, Sherry ST: Genetic traces of ancient demography. Proc Natl Acad Sci USA 1998;95:1961-1967.

7 Liu H, Prugnolle F, Manica A, Balloux F: A geographically explicit genetic map of worldwide human-settlement history. Am J Hum Genet 2006;79:230-237.

8 Tenesa A, Navarro P, Hayes BJ, Duffy DL, Clarke GM, Goddard ME, Visscher PM: Recent human effective population size estimated from linkage disequilibrium. Genome Res 2007; 17:520-526.

-9 McEvoy BP, Powell JE, Goddard ME, Visscher PM: Human population dispersal 'Out of Africa' estimated from linkage disequilibrium and allele frequencies of SNPs. Genome Res 2011;21:821-829.

10 Zhivotovsky LA, Rosenberg NA, Feldman MW: Features of evolution and expansion of modern humans, inferred from genomewide microsatellite markers. Am J Hum Genet 2003;72:1171-1186.
11 Fagundes NJ, Ray N, Beaumont M, Neuenschwander S, Salzano FM, Bonatto SL, Excoffier L: Statistical evaluation of alternative models of human evolution. Proc Natl Acad Sci USA 2007;104:17614-17619.

12 Manica A, Amos W, Balloux F, Hanihara T: The effect of ancient population bottlenecks on human phenotypic variation. Nature 2007; 448:346-348.

13 Amos W, Hoffman JI: Evidence that two main bottleneck events shaped modern human genetic diversity. Proc Biol Sci 2010;277:131137.

$14 \mathrm{Li} \mathrm{H}$, Durbin R: Inference of human population history from whole-genome sequences. Nature 2011;475:493-496.

15 Henn BM, Botiqué LR, Gravel S, Wang W, Brisbin A, Byrnes JK, Fadhlaoui-Zid K, Zalloua PA, Moreno-Estrada A, Bertranpetit J, Bustamente CD, Comas D: Genomic ancestry of North Africans supports back-to-Africa migrations. PLoS Genet 2012;8:e1002397.

16 Henn BM, Cavalli-Sforza LL, Feldman MW: The great human expansion. Proc Natl Acad Sci USA 2012;109:17758-17764.

17 Leutenegger AL, Sahbatou M, Gazal S, Cann $\mathrm{H}$, Génin E: Consanguinity around the world: what do the genomic data of the HGDPCEPH diversity panel tell us? Eur J Hum Genet 2011;19:583-587.

18 The International HapMap Consortium: A second generation human haplotype map of over 3.1 million SNPs. Nature 2007;449:851861.

19 Pemberton TJ, Wang C, Li JZ, Rosenberg NA: Inference of unexpected genetic relatedness among individuals in HapMap Phase III. Am J Hum Genet 2010;87:457-464.

20 Stevens EL, Baugher JD, Shirley MD, Frelin LP, Pevsner J: Unexpected relationships and inbreeding in HapMap Phase III populations. PLoS One 2012;7:e49575.
21 Henn BM, Hon L, Macpherson JM, Eriksson N, Saxonov S, Pe'er I, Mountain JL: Cryptic distant relatives are common in both isolated and cosmopolitan genetic samples. PLoS One 2012; 7:e34267.

22 Bittles AH, Black ML: Evolution in health and medicine Sackler colloquium: consanguinity, human evolution and complex diseases. Proc Natl Acad Sci USA 2010;107:1779-1786.

23 Hamamy H, Antonarakis SE, Cavalli-Sforza LL, Temtamy S, Romeo G, ten Kate LP, Bennett RL, Shaw A, Megarbane A, van Djuin C, Bathija H, Fokstuen S, Engel E, Zlotogora J, Dermitzakis E, Bottani A, Dahoun S, Morris MA, Arsenault S, Aglan MS, Ajaz MK, Alkalamchi A, Alnaqeb D, Alwasiyah MK, Anwer N, Awwad R, Bonnefin M, Corry P, Gwanmesia L, Karbani GA, Mostafavi M, Pippucci T, Ranza-Boscardin E, Reversade B, Sharfi SM, Teeuw ME, Bittles AH: Consanguineous marriages: pearls and perils: Geneva International Consanguinity Workshop Report. Genet Med 2011;13:841-847.

24 Casals F, Hodgkinson A, Hussin J, Idaghdour Y, Bruat V, de Maillard T, Grenier J-C, Gbeha E, Hamdan FF, Girard S, Spinella JF, Larivière M, Saillour V, Healy J, Fernández I, Sinnett D, Michaud JL, Rouleau GA, Haddad E, Le Deist F, Awadalla P: Whole-exome sequencing reveals a rapid change in the frequency of rare functional variants in a founding populations of humans. PLoS Genet 2013;9:e1003815.

25 Yang Y, Muzny DM, Reid JG, Bainbridge MN, Willis A, Ward PA, Braxton A, Beuten J, Xia F, Niu Z, Hardison M, Person R, Bekheirnia MR, Leduc MS, Kirby A, Pham P, Scull J, Wang M, Ding Y, Plon SE, Lupski JR, Beaudet AL, Gibbs RA, Eng CM: Clinical wholeexome sequencing for the diagnosis of Mendelian disorders. N Engl J Med 2013;369: 1502-1511. 
26 Alkuraya FS: The application of next-generation sequencing in the autozygosity mapping of human recessive diseases. Hum Genet 2013;132:1197-1211.

-27 Pippucci T, Benelli M, Magi A, Martelli PL, Magini P, Torricelli F, Casadio R, Seri M, Romeo G: EX-HOM (EXome HOMozygosity): a proof of principle. Hum Hered 2011;72:45-53.

28 Orrù V, Steri MS, Sole G, Sidore C, Virdis F, Dei M, Lai S, Zoledziewska M, Busonero F, Mulas A, Floris M, Mentzen WI, Urru SAM, Olla S, Marongiu M, Piras MG, Lobina M, Maschio A, Pitzalis MS, Urru MF, Marcelli M, Cusano R, Deidda F, Serra V, Oppo M, Pilu R, Reinier F, Berutti R, Pireddu L, Zara I, Porcu E, Wong A, Brennan C, Tarrier B, Lyons R, Kang HM, Uzzau S, Atzeni R,Valentini M, Firinu D, Leoni L, Rotta GL, Naitza S, Angius A, Congia M, Whalen MB, Jones CM, Schlessinger D, Abecasis GR, Fiorillo E, Sanna S, Cucca F: Genetic variants regulating immune cell levels in health and disease. Cell 2013;155: 242-256.
29 Campbell CD, Chong JX, Malig M, Ko A, Dumont BL, Han L, Vives L, O’Roak BJ, Sudmant PH, Shendure J, Abney M, Ober C, Eichler EE: Estimating the human mutation rate using autozygosity in a founder population. Nat Genet 2012;44:1277-1281.

30 Ten Kate LP, Teeuw M, Henneman L, Cornel MC: Autosomal recessive disease in children of consanguineous parents: inferences from the proportion of compound heterozygotes. Community Genet 2010;1:37-40.

31 Gialluisi A, Pippucci T, Anikster Y, Ozbek U, Medlej-Hashim M, Mégarbané A, Romeo G: Estimating the allele frequency of autosomal recessive disorders through mutational records and consanguinity: the Homozygosity Index (HI). Ann Hum Genet 2012;76:159167.

32 Romeo G, Gialluisi A, Pippucci T: Consanguinity studies and genome research in Mediterranean developing countries. Middle East J Med Genet 2012;1:1-4.

33 Gialluisi A, Incollu S, Pippucci T, Lepori MB, Zappu A, Loudianos G, Romeo G: The homozygosity index (HI) approach reveals high allele frequency for Wilson disease in the Sardinian population. Eur J Hum Genet 2013;21: 1308-1311.
34 Dahlberg G: Mathematical Methods for Population Genetics. Basel, Karger, 1947, pp 6167.

35 Romeo G, Menozzi P, Ferlini A, Fadda S, DiDonato S, Uziel G, Lucci B, Capodaglio L, Filla A, Campanella G: Incidence of Friedreich ataxia in Italy estimated from consanguineous marriages. Am J Hum Genet 1983;35: 523-529.

36 Romeo G, Menozzi P, Ferlini A, Prosperi L, Cerone R, Scalisi S, Romano C, Antonozzi I, Riva E, Piceni Sereni L: Incidence of classic $\mathrm{PKU}$ in Italy estimated from consanguineous marriages and from neonatal screening. Clin Genet 1983;24:339-345.

37 Romeo G, Bianco M, Devoto M, Menozzi P, Mastella G, Giunta AM, Micalizzi C, Antonelli M, Battistini A, Santamaria F: Incidence in Italy, genetic heterogeneity and segregation analysis of cystic fibrosis. Am J Hum Genet 1985;37:338-349.

38 Cavalli-Sforza LL, Moroni A, Zei G: Consanguinity, Inbreeding and Genetic Drift in Italy. Princeton, Princeton University Press, 2004. 